\title{
THE PHENOMENON OF NEW WARS: CHANGING NATURE AND VIOLENCE DIPLOMACY
}

\author{
D.I. Strelavina \\ National Research University - Higher School of Economics \\ 20 Myasnitskaya St., Moscow, 101000, Russia
}

The long-term process of a tectonic shift in the chessboard of world affairs has led to the historical formation of different types of wars. The term 'new' is not solely used to describe the new reality of warfare itself, but it is wildly used to outline the multiple aspects of renewed nature of war as well the emerged dimensions of it.

Conflicts of today's show that the weapons of the past are never ideally suited to the future. Mobile, undeclared and at the same unregulated wars lead to the fundamental transformation in the field of military doctrines testimonies. Those who are able to adjust the official military doctrine with newly emerged dimensions of war will be in safe for several decades or more.

Keywords: Hybrid wars, New Wars, Cyber space, Space security, new dimension of war

Introduction. Over thousands of the decades the humans were involved into wars. For the history of ideas, the contribution of ancient Sun Tzu gave a clear view on war's strategies, while Machiavelli and Hobbes outlined an understanding of war as an inseparable part of state formation.

The persistent historical development of arm conflicts starts with the transition of classical wars into the Napoleonic Wars. The end of classical wars was countered by Carl von Clausewitz, who for the first time in history had studied the phenomenon of war on its own. His discussions on the nature of war and strategy commences became a starting point for the long-term process of studying. Being marked by mass military conscription, the Napoleonic Wars were turned to the total war feature. XX century brought an era of total wars and mass murder in the humans' existence, while the destructive power of nuclear weapons as well as a nuclear deterrence slid the world into the Cold War era.

The collapse of the USSR has detonated an extensive discussion in recent literature regarding global strategic trends of modern wars. On the one hand, modern prophets of decreased violence including John Mueller, Steven Pinker, found the violence tend to diminish, while some experts as Edward Luttwak, and, to a less extent, Joshua Goldstein speculate, that the wars do end. 
In contrast, most of scholars in the field of conflict and peace studies such as Gray Chris Hables, Hoffman Frank, Mary Kaldor, are proclaiming the proliferation of the various types of wars. They offered a new vision of modern wars and implements new terminology on it.

\section{The illusion of peaceful time}

In 2014, over 100,000 people were killed in armed conflict [1. P. 4]. That has become the highest fatality count since the end of Cold War, according to the latest Human Security Report. Nevertheless the Human Security Report, the Uppsala Conflict Data Program (UCDP) [2], with a company of enormous number of scholars (S. Pinker [3], J. Mueller [4]) claims that the violence has been in decline. E. Luttwak has pointed the argument of unrealistic perspective of war [5. P. 365], while J. Goldstein speculates on progress and declining violence [6. P. 237].

Harvard psychologist Steven Pinker is often painted as the chief interpreter of the decline of violence. Reviewing the statistical numbers and historical datasets through the prism of the number of those killed in violent conflicts, Pinker infers several major historical declines of violence. The past was more violent than the current time in our humans' existence.

There is a certain truth to those statements. Analyzing the millennia of slaughter, haunter-gatherer periods, barbaric and tribal practices of human sacrifice, status of women, children's welfare and human rights in toto, we would come to the moral progress of the society.

However, the declining trend of violence is one of the most arguable questions. Despite it was scientifically assessed, Pinker's book 'The Better Angles of Our Nature: a history of violence and humanity' is short on methodological part. Periodic comparative ranking is less important than growing transformation of violence capabilities.

Turning to the difficult context of distinctions of violence, peace and conflict studies scholar Johan Galtung creates a typology of violence. This indicates violence can take many worms such as: physical and psychological violence, personal and structural; intended and not intended; manifest and latent [7. P. 167-191].

The definition of war coined by Carl von Clausewitz in his path-breaking book 'On War' emphasis on 'war therefore is an act of violence to compel our opponent to fulfill our will' [8. P. 62]. What we intend is only that the terms 'war' and 'violence' are linked to each other such that 'war' can be regarded as 'an act of violence', while the 'violence' is not defined by the brute power only. In the middle of $\mathrm{XX}^{\text {th }}$ his ideas were developed by Thomas Shelling, who infers 'military strategy.. has become the diplomacy of violence' [9. P. 34].

In other words, the violence is much more than physical or armed forces alike. The violence also consists of actions that cause an emotional, physical and psychological damage, as well as a mental abuse. Thus, it could not be marked by the number of deaths, whether on war battlefields or not. 


\section{New dimensions of war}

In recent years military analysts and international relations theorists often reject the ideas of Clausewitz as outdated. Whether due to XIX ${ }^{\text {th }}$ century's wars were not as developed as current ones, Clausewitz could not have written about naval matters, air combat, nuclear weapons, and cyber or space warfare. However, his idea on war as an act of violence is far from being irrelevant.

The early history illustrates two-space dimensions of battlefields have been dominant for the classical type of ground and sea wars. The third dimension of military operations as the air land battles has been explored at the height of the WWII. The formation of air forces has become the first priority for each single country until the start of the nuclear age (1). With nuclear weapons the cost of war has become significantly high and that risk let the violence of diplomacy goes forward.

The space and the cyberspace have become the fourth and the fifth dimensions of war respectively [9. P. 3]. Those who study the problem of wars usually point to the phenomenon of media wars. The mainstream media disinformation as well as it's versus as media propaganda in a company with the influence of media itself also should be taken into account.

Thus, the new era of ware fare, the effects of globalization, the media revolution bring us new forms of violence, which are highly connected with a phenomenon of so called new wars or hybrid wars.

Many contemporary thinkers put the terms of new wars very simply, that rich the field of the study: the 'wars of the third kind' [10], the 'wars with law intensity', 'the 'hybrid wars' [11. P. 52], the 'privatized wars', the 'post-modern wars' [12], the 'network operations' [13] and the 'new wars' [14]. But the important point here is there is no definition what exactly the each of this war is.

In order not to overwork the research with examples of the term's definitions we shall refer to the concrete example one can point the problem out. The primer international assessment of the military capabilities and defence economics 'Military Balance 2015' depicts the 'hybrid war' as 'the methods applied included the use of military and non-military tools in an integrated campaign designed to achieve surprise, seize the initiative and gain psychological as well as physical advantages utilising diplomatic means; sophisticated and rapid information, electronic and cyber operations; covert and occasionally overt military and intelligence action; and economic pressure' [15. P. 2]. That displays the idea of undeclared boundaries of new wars.

Through an engagement with Clausewitz' concept of war as violence, each of the term as "hybrid war", "new war" and even an informational war is an umbrella term of a blurred vision of new dimensions of warfare, which violence is permeated through.

\section{The problem of unconventional warfare}

The war as an exclusive state's instrument of violence and brutal force is not ideally suited for the 'new wars' [14. P. 15]. Under such an approach, low-intensity 
conflicts does not match the changing nature of Clausewitz's 'On War' commences [16. P. 37]. In the globalized and well technologically prepared world, the conflicts are becoming more characterized by non-state actors.

The increasing numbers of new forms of non-state actors simultaneously led to the security challenges. Groups sponsored by states, non-state actors, and private armies, commanders, drug traffickers, terrorists and urban criminal networks get an access to the warfare capacities, power of which is similar to those nation-states own [17. P. 369].

The state actors are the main participants of the war does not universally correspond to current events any more. But wars can never be isolated from a political context [8. P. 20]. This trend required a review of the way security measures are viewed and implemented in the field of IR. Neither technologically advantage of armed forces no professionalism of intelligence agencies could not be considered the war in toto.

In this way, the contingent factors and unknowns make the new wars difficult to regulate. The nature of modern wars does not set the boundaries of actions whether let alone legal violation or brute justification. Additionally, there is no international consensus about law regulation, which could help to adjust limits of hostile action and foreign involvement. Neither the threat no the possible use of new kinds of warfare are unregulated. The rules of international law applicable in armed conflict, and in particular the principles and rules of humanitarian law have no a single line concerning acts of violence in new areas of war.

To make new wars adapted to international security is necessary to rethink the role of both state and non-state actors, as well as the increasing role of cyber, media and information in battlefields. The new legal instruments and clarification of the permissible bounds of actions should be found. Otherwise, this will lead to the legitimate use of violence in the newly discovered areas.

Conclusion. Over long stretches of time the principles of war were correspondent with the moral and technological progress of human kinds. However, new reality let the pendulum swing the other forms of new wars. The newly discovered dimensions of war such as space and cyber space have brought a significant change in the understanding of military strategies.

The nature of renewed emerged wars is specifying by the effects of globalization, the media and the technology revolution. Being a nonkilling, but a powerful tool of influence, the latent violence is permeated through the new dimensions of wars. Initially, based on violence the war is characterized by a brute force and coercive violence alike.

The tricky problem of attribution makes the new wars difficult to develop international consensus about it. Conflicts of today's world show us that the weapons as well as a law regulation of the past are never ideally suited to the future. Mobile, undeclared and at the same unregulated wars limit victims in a self-protection of 
that violence. Also, the environment has not formatted conventional warfare as well as legal manual of action in response to the new wars. Thus, this situation will lead to the tectonic shifts in the military doctrines so far.

(C) Strelavina D.I., 2018

\section{APPENDIX}

(1) This period usually considered to have begun with the first appearance of the atomic bomb on 16 July 1945, when the US tasted a new type of weapon.

\section{REFERENCES}

[1] Human Security Report 2013. The Decline in Global Violence: Evidence, Explanation, and Contestation, Vancouver: Human Security Press, 2013.

[2] Melander E. Organized Violence in the World 2015. An assessment by the Uppsala Conflict Data Program http://www.pcr.uu.se/digitalAssets/61/c_61335-1_1-k_brochure2.pdf.

[3] Steven P. The Better Angels of Our Nature: a history of violence and humanity. London: Penguin Books Ltd, 2012.

[4] Mueller J. Retreat from Doomsday: The Obsolescence of Major War. N.Y.: Basic Books, 1989.

[5] Luttwak E. Strategy The Logic of War and Peace. Cambridge: The Belknap Press of Harvard University Press, 2003.

[6] Goldstein J. Winning the War on War: The Decline of Armed Conflict Worldwide. N.Y.: Plume, 2012.

[7] Galtung J. Cultural Violence // Journal of Peace Research. Vol. 6, No. 3, 1969.

[8] Clausewitz C. On War. N.Y.: Oxford University Press, 1976.

[9] Shelling T. Arms and Influence. Virginia: BookCrafters, Inc., 1966.

[10] Kokoshin A. Several Dimensions of War // Voprosy Filosofii. Vol. 8, 2016.

[11] Rice E. Wars of the Third Kind: Conflict in Underdeveloped Countries. London: University of California Press, 1988.

[12] Hoffman F. Hybrid Warfare and Challenges // Joint Force Quarterly. Vol. 52, 2009.

[13] Gray C. H. Postmodern War: the New Politics of Conflicts. N.Y.: The Guilford Press, 1997.

[14] Ignatieff Michael. I Human Rights as Politics. II. Human Rights as Idolatry // The Tanner Lectures ion Human Values. Princeton University, 2000.

[15] Kaldor M. New and Old Wars. Organized Violence in a Globalized Era. Stanford: Stanford University Press, 2003.

[16] The Military Balance 2015. The International Institute for Strategic Studies: 2015.

[17] Creveld M. The Transformation Of War. N.Y.: The Free Press, 2004.

[18] Arquilla J., Ronfeldt D. Networks and Netwars. The Future of Terror, Crime, and Militancy. Santa Monica: RAND, 2001. 


\title{
ФЕНОМЕН НОВЫХ ВОЙН: ОБНОВЛЕННАЯ ПРИРОДА КОНФЛИКТОВ И ДИПЛОМАТИЯ НАСИЛИЯ
}

\author{
Д.И. Стрелавина \\ Национальный исследовательский университет - \\ Высшая школа экономики \\ ул. Мясницкая, 20, Москва, Россия, 101000
}

На протяжении десятилетий структурные изменения на международной арене политических отношений формируют феномен новых войн. Аспект «новых» войн зачастую не связан исключительно с модернизированными версиями вооружений, но однозначно является следствием открытия обновленной природы конфликтов и новейших измерений для ведения военных действий.

Средства и методы ведения войн, которые были эффективны в прошлом, становятся неактуальными в современных условиях. Динамичные, нерегулируемые и в то же время необъявленные войны ведут к фундаментальным изменениям военных доктрин будущего.

Ключевые слова: новые войны, новые измерения войны, гибридные войны, кибербезопасность, цифровое пространство, безопасность космического пространства

\section{Информация об авторе / Information about the author}

Стрелавина Дарья Игоревна - магистрант Школы востоковедения факультета мировой экономики и мировой политики Национального исследовательского университета «Высшая школа экономики». E-mail: dstrelavina@gmail.com

Daria Strelavina - student at National Research University - Higher School of Economics.E-mail: dstrelavina@gmail.com

\section{Для цитирования / For citations}

Стррелавина Д.И. Феномен новых войн: обновленная природа конфликтов и дипломатия насилия / Вестник Российского университета дружбы народов. Серия: ВСЕОБЩАЯ ИСТОРИЯ. 2018. ТОМ 10. № 2. С. 201-206. DOI: 10.22363/2312-8127-2018-10-2201-206.

Strelavina D.I. The Phenomenon of New Wars: Changing Nature and Violence Diplomacy / RUDN JOURNAL OF WORLD HISTORY. 2018. 10(2): 201-206. DOI: 10.22363/23128127-2018-10-2-201-206.

Рукопись поступила в редакцию / Article received: 22.06.2017 